\title{
State of Food (in)Security in Chepang Community: A Case of Dahakhani VDC, Chitwan \\ Badri Aryal*
}

\begin{abstract}
This study intends to investigate food (in)security situation of Chepang communities as well as their food coping strategies based on 48 sample households in Dahakhani Village Development Committee, Chitwan. On an average they possesses low level of assets and meager amount of crops and animal husbandry products. Consequently, most of the Chepang are found food insecure. Social services like school and drinking water sources are supplied within half an hour walking distance from their home whereas roads, health and agriculture service centre, markets and financial institutions are 3 hours far from home. Correlation analysis showed highly significant relationship between number of food insufficient months and number of livestock and birds in the household; between number livestock and birds with quantities of cereal production in a year. There is significant association of quantity of cereal production and land holding size with number of food insufficient months for a year. It can be inferred that meat is one of the important component of Chepang food habit and promotion of livestock raising can be an important supplement to Chepang diets.
\end{abstract}

Keywords: Chepang, indigenous people, marginalized communities, food (in)security.

\section{INTRODUCTION}

Nepal is a home to nearly 26.6 million people, which comprises numerous multi-ethnic, multilingual and multi-religious groups (CBS, 2010). The Government of Nepal has identified and recognized 59 indigenous nationalities of Nepal through the enactment of the National Foundation for Development of Indigenous Nationalities Act, 2002. Nepal Federation of Indigenous Nationalities (NEFIN), 2004 has further classified the 59 indigenous groups into five groups comprising of endangered, highly marginalized, marginalized, disadvantaged and advantaged group. Chepang population in Nepal is 68,399 which comprise 0.26 per cent of total population of Nepal (CBS, 2011 and percent calculation by author) is one of the highly marginalized groups living on the hilly and steeper slopes of Chitwan, Dhading, Gorkha, Makawanpur, Lamjung and Tanahu districts of Nepal (NCA, 2004). The primary lifestyle of the community includes hunting, foraging for wild roots, fishing and traditional farming near forests (Gurung, 1995).

Chepang are considered to be the youngest communities to instigate agriculture in Nepal. Chepang are known as people living in hills with difficult physiographic (Rai, 1985). Their traditional settlements lie on steep slopes in the Mahabharat and Churia range between 500 to 1500 metre above sea level. However, these days Chepang settlements are also found below 500 metre above sea level. Two modes

* Mr. Aryal is Lecturer at School of Development and Social Engineering, Pokhara University, Lekhnath. 
of agriculture are practiced in Chepang community; the first one is their indigenous slash-and-burn farming, and the second one is terrace farming in permanent agricultural land. According to Caughley et al., (1971) Chepang started agrarian life only recently i.e. some 120 years ago; before that they used to live partly in forests and caves. The maize production can suffice only six months in a year (Gurung, 1995). In recent years, Chepang have also started commercial vegetable farming on small scale. The important hindrance in their agro-practice is unavailability of irrigation facility. Similarly, insufficient land with difficult topography, poor land husbandry and their traditional life style are other factors limiting food production. Large labor input in agriculture hardly supports their subsistence even at present.

Among Chepangs, $77 \%$ are illiterate, $71 \%$ of the children are malnourished and $80 \%$ of the eligible Chepangs are denied for Citizenship Certificate and almost half of them are deprived from receiving land registration certificate (NCA, 2004).

Food self-insufficiency and food insecurity along with nutrition securtiy is the most prominent issue in the livelihoods of Chepang community. Only a small percentage of Chepang households are fully selfsufficient. Thus they adopt multi-pronged livelihood strategies like wage labor, collection of forest products rearing small livestock, selling bamboo handicrafts, and selling agriculture and forest products ( FORWARD, 2001).

The present study intends to assess food (in)security situation among Chepang community of Chitwan district and their food coping strategies.

\section{The Study Site and Sample}

\section{DATA AND METHODS}

The study area is purposively selected for the study. Chitwan, Makawanpur and Dhading districts are the districts with the highest population concentration of Chepangs in Nepal (CBS, 2011). Chitwan district lies in between Makawanpur and Dhading districts. Dahakhani VDC has significant number of Chepang Communities, is relatively less accessible as there is no motorable road to the VDC and is representatives in all social, economic and cultural variables of Chepang communities. Total number of Chepang households in Dahakhani VDC is 589(DDC, 2007). Among them 48 households are selected for questionnaire schedule entertainment and data generation.

\section{Techniques of data collection and Analysis}

Chepang households are the key source of the primary data. Besides, the information obtained through semi-structured interview schedule, Focus Group Discussion (FGD) and Key Informant Interview (KII) are conducted. The information collected from the field survey is coded first and entered into the computer. Data entry and analysis is done by using computer software package like Statistical Package for Social Science (SPSS 16 version) and Microsoft Excel. Assessment of the socio-economic features of the Chepang community is carried out through the descriptive statistics. Descriptive statistics like frequency count, percentage, charts and diagrams is estimated. Correlation analysis is done to see the relation between variables and their significance level. 
Type and size of holding

\section{RSULTS AND DISCUSSION}

A descriptive statistics regarding the type of land and size of holding by each household is analyzed. Major types of lands the Chepang families possess are pakhobari, irrigated khet, and khoria.

Table 1: Descriptive statistics for the type and size of land holding

\begin{tabular}{|l|c|c|c|c|c|c|c|}
\hline Type and area of land & Range & Minimum & Maximum & \multicolumn{2}{|c|}{ Mean } & $\begin{array}{c}\text { Std. } \\
\text { Deviation }\end{array}$ & Variance \\
\hline & Statistic & Statistic & Statistic & Statistic & Std. Error & Statistic & Statistic \\
\hline pakho bari (kattha) & 60 & 0 & 60 & 16.06 & 2.114 & 14.647 & 214.528 \\
\hline khet irrigated( kattha) & 20 & 0 & 20 & 1.21 & .595 & 4.120 & 16.977 \\
\hline khoria( kattha) & 30 & 0 & 30 & 3.88 & 1.406 & 8.201 & 67.258 \\
\hline $\begin{array}{l}\text { Total land area in } \\
\text { kattha) }\end{array}$ & 60 & 0 & 60 & 20.02 & 2.290 & 15.864 & 251.680 \\
\hline
\end{tabular}

Source: Field Survey, 2012.

Table 1 clearly reveals the size of holding and their characteristics. Maximum size of pakho bari is 60 katha per household, irrigated khet 20 katha and khoria 30 katha whereas the minimum size for the respective categories is 0 katha. Average size of holding for pakho is 16 katha, for khet it is 1 katha and for khoria it is nearly 4 katha with standard deviation of 14.647 for pakho, 4.12 for khet and 8.201 for the khoria with standard error $2.114,0.595$ and 1.406 for the respective categories.

\section{Type and quantity of Crops and Livestock}

Major crops grown by the Chepang families are cereals which thrive in the rain fed situation like maize, millet, buckwheat. They grow pulses to sell them in cash or for exchange them with rice and other cereals.

Table 2: Descriptive statistics for types of crops and livestock raised

\begin{tabular}{|l|c|c|c|c|c|c|c|}
\hline \multirow{2}{*}{ Description } & Range & Minimum & Maximum & \multicolumn{2}{|c|}{ Mean } & Std. Deviation & Variance \\
\cline { 2 - 8 } & Statistic & Statistic & Statistic & Statistic & Std. Error & Statistic & Statistic \\
\hline $\begin{array}{l}\text { Quantity of cereal grown in a year } \\
\text { (muri) }\end{array}$ & 36 & 0 & 36 & 10.77 & 1.428 & 9.787 & 95.781 \\
\hline $\begin{array}{l}\text { Quantity of pulses grown in a } \\
\text { year(pathi) }\end{array}$ & 115 & 0 & 115 & 24.39 & 4.542 & 27.250 & 742.587 \\
\hline No of cow and bullocks & 14 & 0 & 14 & 4.95 & .496 & 3.215 & 10.339 \\
\hline No of buffalos & 5 & 0 & 5 & 2.08 & .431 & 1.553 & 2.410 \\
\hline No of goats & 22 & 0 & 22 & 8.30 & .976 & 5.934 & 35.215 \\
\hline No of pigs & 7 & 0 & 7 & 1.73 & .675 & 2.240 & 5.018 \\
\hline No of poultry birds & 12 & 0 & 12 & 6.14 & .643 & 3.461 & 11.980 \\
\hline
\end{tabular}

Source: Field Survey, 2012.

Table 2 describes the major crops and livestock's including poultry birds raised by Chepang families in the study area. Major types of livestocks they rear are cow, buffaloes, goats, pigs and poultry birds. Their 
State of Food (in)Security in Chepang Community.../63

range, mean and standard deviation as well as standard error and variance have been presented in the table. Chepang are deft in handling honey bees in traditional beehives which is seen in very small scale in the study area; so it is not shown in the databases.

\section{Availability of Social and Institutional Services}

Human and economic development of the place is greatly influenced by the availability of various social overheads. The list shows the distances to school for the kids, health posts, veterinary services, major market centre, banks and financial intermediaries, road heads and sources to drinking water.

Table 3: Descriptive statistics showing average distances of different social services

\begin{tabular}{|c|c|c|c|c|c|c|c|}
\hline \multirow{2}{*}{$\begin{array}{c}\text { Distances to different social } \\
\text { services from Chepang } \\
\text { settlement }\end{array}$} & \multirow{2}{*}{\begin{tabular}{|l} 
Range \\
Statistic
\end{tabular}} & \multirow{2}{*}{\begin{tabular}{|l|} 
Minimum \\
Statistic
\end{tabular}} & \multirow{2}{*}{\begin{tabular}{|l|} 
Maximum \\
Statistic \\
\end{tabular}} & \multicolumn{2}{|c|}{ Mean } & \multirow{2}{*}{$\begin{array}{c}\text { Std. } \\
\text { Deviation }\end{array}$} & \multirow{2}{*}{\begin{tabular}{|l|} 
Variance \\
Statistic
\end{tabular}} \\
\hline & & & & Statistic & $\begin{array}{l}\text { Std. } \\
\text { Error }\end{array}$ & & \\
\hline $\begin{array}{l}\text { School for the kids (minutes } \\
\text { walking) }\end{array}$ & 119 & 1 & 120 & 41.06 & 4.195 & 29.065 & 844.783 \\
\hline $\begin{array}{l}\text { Health post or health centers(hours } \\
\text { walking) }\end{array}$ & 4 & 1 & 5 & 2.73 & .135 & .934 & .872 \\
\hline $\begin{array}{l}\text { Agriculture and veterinary } \\
\text { services (hours walking) }\end{array}$ & 4 & 1 & 5 & 2.75 & .144 & .995 & .989 \\
\hline Market centre (hours walking) & 4 & 1 & 5 & 2.73 & .147 & 1.021 & 1.042 \\
\hline $\begin{array}{l}\text { Bank or financial } \\
\text { cooperatives(hours walking) }\end{array}$ & 4 & 1 & 5 & 2.92 & .170 & 1.178 & 1.387 \\
\hline Nearest road head(hours walking) & 4 & 1 & 5 & 2.77 & .143 & .989 & .978 \\
\hline $\begin{array}{l}\text { Sources of drinking water(minutes } \\
\text { walking) }\end{array}$ & 120 & 0 & 120 & 29.17 & 3.906 & 27.060 & 732.270 \\
\hline
\end{tabular}

Source: Field Survey, 2012.

Table 3 shows various social services available to the study settlements. Distance to school and drinking water source is measured in minutes and other social services in hours walking on foot distances. Various statistical interpretations are displayed in the table which speaks the range, mean value, standard error, standard deviation and variance. Average distance to school is 41 minutes and average distance to fetch drinking water is 29 minutes on walking. Average distance to travel for health centers, market centre, road head is nearly 2.75 hours whereas distance to financial institutions is little bit longer averaging 2.92 hours.

\section{Number of food in/sufficient months}

Chepang communities are suffered from food insecurity situation. Table 4 shows the total food insufficient months during a year for the Chepang famlies. Only 6 percent of the Chepang households are food secure round the year and rest 94 percent are food insecure. Based on 3 months of food insufficiency as relatively food secure or transient food insecure situation and place the 4 or more months 
as chronic food insecure category, relatively food secure or transient food insecure families are only 19 percent and rest 81 percent Chepang families are chronically food insecure.

Table 4: Number of food insufficient months for the Chepang families

\begin{tabular}{|c|c|c|c|}
\hline No of food insufficient months & No of households & Percent & Cumulative Percent \\
\hline 0 & 3 & 6.2 & 6.2 \\
\hline 2 & 2 & 4.2 & 10.4 \\
\hline 3 & 4 & 8.3 & 18.8 \\
\hline 4 & 2 & 4.2 & 22.9 \\
\hline 5 & 5 & 10.4 & 33.3 \\
\hline 6 & 9 & 18.8 & 52.1 \\
\hline 7 & 9 & 18.8 & 70.8 \\
\hline 8 & 10 & 20.8 & 91.7 \\
\hline 9 & 2 & 4.2 & 95.8 \\
\hline 12 & 2 & 4.2 & 100.0 \\
\hline Total & 48 & 100.0 & 100.0 \\
\hline
\end{tabular}

Source: Field Survey, 2012.

\section{Coping strategies for the food shortages}

As per the table 5, it seems that only 6 percent Chepang families are food sufficient round the year and do not need to rely on the alternative sources for feeding their families whereas rest 94 percent Chepang families need alternative feeding sources for the families. Table 5 reveals their food coping strategies.

Table 5: Major food management strategies for Chepang families

\begin{tabular}{|l|c|c|}
\hline Major food strategies & Number & Percent \\
\hline Wage labor earning and wild edibles & 22 & 45.8 \\
\hline Wage labor earning only & 14 & 29.2 \\
\hline Alternative foods not needed & 3 & 6.2 \\
\hline Borrowing from neighbors and relatives & 2 & 4.2 \\
\hline Wage labor, service and wild edibles & 2 & 4.2 \\
\hline Wage labor earning and service & 2 & 2.2 \\
\hline Self business only & 1 & 2.1 \\
\hline Service earning only & 1 & 2.1 \\
\hline Wild edibles only & 1 & 100.0 \\
\hline Total & 48 & \\
\hline
\end{tabular}

Source: Field Survey, 2012. 
State of Food (in)Security in Chepang Community.../65

45 percent Chepang adopt both wage labor and wild edibles as alternatives to regular food supplys. 29 percent are solely dependent on wage labor earning to supplement their diets. Other coping strategies are in smaller percentages and can be seen as mixture of several strategies.

The type of wild edibles here deserve especial mention. Even today, Chepangs consume the fruits of Chiuri (Bassica butyracea), Khaniya( a kind of fig tree) and Newara( a kind of fern from which young shoots are eaten).They collect leaves and fruits of nettles, takis, koirala flower(name of a tree, Bauhinia variegate),Githa( the plant Diascorea sativa) Bhyakur ( a kind of creeper, the roots of which are eaten), odal (Stercuria villosa, tree from which fibres are obtained) and Bharlang ( the shoot of which is spiny shrub and the root is eaten). Chepang still collect insects to eat along with for the collection of honey and wax ( Gurung, 1990). They collect ryank ( a kind of wasp), aringal (hornets) and ngol ( a kind of poisonous insect). They are conversant with the use of bows and arrows, and their hunting consists mostly of trapping and snaring animals with the assistance of dogs which accompany them on their wanderings. The animals which Chepangs want to hunt are ghoral( wild Himalayan goat), mirga(deer),banel(wild boar).They kill small birds like jureli(lingsherva), kotero(brit), phista (marvangra) and others.

Being a good fishermen, Chepangs practice fishing throughout the year as a vital part of their subsistence economy. Still more interesting in their fooding habit is they serve their food in a Tapari( small dish made of leaves) and divide the total food equally among all members in a family including children and fetuses, the share of which goes to the mother(based on focus group discussion).

\section{Correlation Analysis}

Correlation analysis is done to see the relation between variables. The magnitude and direction of relationship between number of livestock and landholding size, quantity of cereal production and number of food insufficient months were analyzed. Correlation analysis result of the relationships between variables is presented in table.

Table 11: Correlation between total number of livestock and birds, landholding size and cereals grown with food insufficient months for a year

\begin{tabular}{|c|c|c|c|c|c|}
\hline Variables & Test statistics & $\begin{array}{c}\text { Number of } \\
\text { food } \\
\text { insufficient } \\
\text { months }\end{array}$ & $\begin{array}{c}\text { Total } \\
\text { number of } \\
\text { livestock } \\
\text { and birds }\end{array}$ & $\begin{array}{c}\text { quantity of } \\
\text { cereal } \\
\text { production }\end{array}$ & $\begin{array}{c}\text { Total land } \\
\text { area }\end{array}$ \\
\hline \multirow{2}{*}{$\begin{array}{l}\text { Number of food } \\
\text { insufficient months }\end{array}$} & Pearson Correlation & 1 & $-.479^{* *}$ & $-.359^{*}$ & $-.324^{*}$ \\
\hline & Sig. (2-tailed) & & .001 & .013 & .024 \\
\hline \multirow{2}{*}{$\begin{array}{l}\text { Total number of livestock } \\
\text { and birds }\end{array}$} & Pearson Correlation & $-.479^{* * *}$ & 1 & $.452^{* *}$ & .285 \\
\hline & Sig. (2-tailed) & .001 & & .002 & .055 \\
\hline \multirow{2}{*}{$\begin{array}{l}\text { quantity of } \\
\text { production }\end{array}$} & Pearson Correlation & $-.359^{*}$ & $.452^{* *}$ & 1 & $.496^{* *}$ \\
\hline & Sig. (2-tailed) & .013 & .002 & & .000 \\
\hline \multirow[t]{2}{*}{ Total land area } & Pearson Correlation & $-.324^{*}$ & .285 & $.496^{* *}$ & 1 \\
\hline & Sig. (2-tailed) & .024 & .055 & .000 & \\
\hline
\end{tabular}

Source: Field Survey, 2012. 
Correlation analysis reveals a highly significant relationship between number of livestock and landholding size and with number of food insufficient months in a year. Number of livestock raised has positive correlation with the quantity of cereal grown and negative correlation with the number of food insufficient months. So also there is highly significant relationship between total land holding size and amount of cereal grown in a year. There is significant association between total landholding and quantity of cereal grown with food insufficient months; but both in a negative way. There is positive relationship between total landholding size and number of livestock raised but is statistically not significant.

\section{CONCLUSION}

The indigenous nationalities are generally lagging behind in most of the social economic and human development variables. Chepang being the highly marginalized indigenous group of our land, their nomadic life in the relatively less remote periods than other tribes, slash and burn type subsistence agriculture and exposure to less productive resources put them behind average people of the country. This study has brought forward some interesting tradition of Chepang people more specifically to their fooding habit. They are basically food insecure people and adopt a multitude of sources like wage earning and scavenging to wild edibles to supplement their diets.

\section{REFERENCES}

Caughley, R.C., Dahal, B.M. and Bandhu, C.M. 1971. Notes on Chepang culture.Journal of Tribhuvan University 6(1): 77-89.

CBS, 2010. Preliminary Result of the Population and Household Census of Nepal, Central Bureau of Statistics, Kathmandu

CBS, 2011. National Population Census; A Brief Report (in Nepali), Central Bureau of Statistics, Kathmandu

DDC, 2007. Chitwanka Aadiwasi Janajatiko Samajik Ra Sanskritic Adhyayan(in Nepali), District Development Committee(ed) by Bishnu Prasad Ghimire, Bharatpur, Chitwan P 31.

FORWARD. 2001. Formulation of a comprehensive praja development program. Part II. Prepared for Ministry of Local Development, Kathmandu and SNV-Nepal, Chitwan, Nepal.Forum for Rural Welfare and Agriculture Reform for Development.

Gurung G.M. 1995. Report from a Chepang Village: Society, Culture and Environment. Kathmandu, Nepal.

NCA, 2004. Project Document of Chepang Mainstreaming Programme; Nepal Chepang Association, Kathmandu

Rai, N.K. 1985. Peoples of the Stones; the Chepang of the Central Nepal. Center for Nepal and Asian Studies (CNAS), Tribhuvan University, Kathmandu, Nepal. 